\title{
EFEKTIFITAS PELATIHAN PEER EDUCATOR TERHADAP PENINGKATAN PENGETAHUAN, KETERAMPILAN DAN PERUBAHAN SKOR BODY IMAGE REMAJA PUTRI SMAN 4 PURWOKERTO
}

\section{Effectiveness Of Peer Educator Training In Knowledge Improvement, Skills And Changes Score Of Body Image In Young Women Sman 4 Purwokerto}

\author{
Rima Sumayyah Ahmad ${ }^{1}$, Erna Kusuma Wati ${ }^{2}$, Elviera Gamelia ${ }^{3}$ \\ ${ }^{1}$ Ilmu Gizi Universitas Jenderal Soedirman \\ ${ }^{2}$ Bagian Gizi Masyarakat, Universitas Jenderal Soedirman \\ ${ }^{3}$ Bagian Ilmu Promosi Kesehatan, Universitas Jenderal Soedirman
}

\begin{abstract}
Body image is one of the causes of eating behavior deviates in addition to genetic factors and low self confidence. Knowing the effectiveness of peer educators training in improving the knowledge, skills and scores of body image of young women in SMAN 4 Purwokerto. This study used a quasi-experimental design with one group pretest posttest. The study was conducted in SMA Negeri 4 Purwokerto. Samples were 39 young women and were aken by purposive sampling. The results of statistical tests using the Wilcoxon test was obtained grades A Sym. Sig. $(2$-tailed $)=0.000(<0.05)$ in all study variables means statistically there are differences in knowledge of body image, peer educator knowledge, body image score and skills of young women SMAN 4 Purwokerto significant before and after training. Peer educators training is effective in improving knowledge, skills and scores of body image of young women in SMAN 4 Purwokerto
\end{abstract}

Keywords: Peer Educator, Body Image, Young Women

\begin{abstract}
Abstrak
Body image merupakan salah satu faktor penyebab perilaku makan menyimpang disamping faktor genetik dan kepercayaan diri yang rendah. Mengetahui efektifitas pelatihan peer educator dalam meningkatkan pengetahuan, keterampilan dan skor body image remaja putri di SMAN 4 Purwokerto. Penelitian ini menggunakan metode kuasi eksperimen dengan rancangan one group pretest posttest. Penelitian dilakukan di SMA Negeri 4 Purwokerto. Sampel penelitian ini adalah 39 remaja putri yang diambil secara purposive sampling. Hasil uji statistik dengan menggunakan uji Wilcoxon diperoleh nilai A Sym. Sig. $(2$-tailed $)=0,000(<0,05)$ pada semua variabel penelitian artinya secara statistik menunjukan ada perbedaan pada pengetahuan body image, pengetahuan peer educator, skor body image dan keterampilan remaja putri SMA Negeri 4 Purwokerto yang signifikan sebelum dan sesudah pelatihan. Pelatihan peer educator efektif dalam meningkatkan pengetahuan, keterampilan dan skor body image remaja putri di SMAN 4 Purwokerto.
\end{abstract}

Kata Kunci: Peer Educator, Body Image, Remaja Putri 


\section{PENDAHULUAN}

Body image merupakan salah satu penentu kehidupan sosial dan masa depan memasuki era 90-an, perempuan disibukkan dengan bagaimana cara membuat citra yang menarik mengenai diri mereka dan lingkungannya. Pada masa remaja awal, remaja perempuan kurang puas dengan tubuhnya dan memiliki citra tubuh yang lebih negatif selama pubertas, dibandingkan dengan remaja laki-laki. Pada saat yang sama, laki-laki semakin puas dengan tubuhnya yang menjadi lebih berotot setelah pubertas (Papalia et.al, 2008). Body image adalah penilaian seseorang tentang ukuran tubuh, penampilan, dan fungsi setiap bagian tubuhnya (Kozier, 2004). Penelitian dari Syarafina dan Probosari (2014) seseorang yang memiliki body image negatif cenderung melakukan perilaku makan yang tidak baik. Perilaku makan tidak baik yang dilakukan remaja dalam penelitian ini sebanyak 43 subjek $(72.8 \%)$ yaitu makan tidak teratur atau sering melewatkan waktu makan tertentu.

Esther (2002) menemukan beberapa fakta, yaitu $62 \%$ subjek penelitian ingin menurunkan berat badan setelah menonton acara peragaan busana dan penampilan para artis di televisi dan $75 \%$ subjek penelitian yang suka membaca artikel tentang bentuk tubuh yang langsing di media cetak merasa tidak puas dengan citra tubuh mereka. Treasure dan Murphy (2005) dalam Gibney et al (2005) mengatakan bahwa body image merupakan salah satu faktor penyebab perilaku makan menyimpang disamping faktor genetik dan kepercayaan diri yang rendah. Perilaku makan menyimpang atau biasa disebut eating disorders adalah gangguan perilaku makan yang kompleks dan sangat berpotensi mempengaruhi pertumbuhan, perkembangan mental dan aktivitas fisik (Brown, 2005). Penelitian dari Syarafina dan Probosari (2014) seseorang yang memiliki body image negatif cenderung melakukan perilaku makan yang tidak baik.

Studi pendahuluan mengenai body image di SMAN 4 Purwokerto Tahun 2016 didapatkan hasil bahwa 26,67 \% remaja putri tidak puas pada body imagenya. Dibutuhkan pendidikan kesehatan yang tepat untuk remaja yang salah satunya dengan metode pendidikan teman sebaya (peer group). Penelitian (Rahayu, 2008) menyimpulkan bahwa promosi kesehatan dengan menggunakan metode peer educator efektif untuk meningkatkan pengetahuan maupun memperbaiki sikap remaja tentang HIV/AIDS. Tujuan penelitian yang dilakukan 
adalah mengetahui efektifitas pelatihan pelatihan peer educator dalam meningkatkan pengetahuan, keterampilan dan skor body image remaja putri di SMAN 4 Purwokerto.

\section{METODE PENELITIAN}

Penelitian ini menggunakan jenis penelitian kuasi eksperimen dengan rancangan one group pretest posttest. Penelitian ini dilakukan di SMA Negeri 4 Purwokerto yang beralamat di Kabupaten Banyumas. Besar sampel dalam penelitian ini adalah 39 orang dengan kriteria inklusi remaja putri berusia 15-17 tahun, bersedia menjadi subjek penelitian, memiliki ketertarikan di bidang kesehatan, aktif organisasi, menjadi perwakilan setiap kelas dan menjadi rekomendasi guru bidang Kemahasiswaan SMAN 4 Purwokerto. Kriteria eksklusi pada penelitian ini adalah responden tidak hadir saat dilakukan pelatihan. Teknik sampling dalam penelitian ini menggunakan teknik purposive sampling. Metode analisis yang digunakan pada masing-masing variable adalah uji Wilcoxon.

\section{HASIL DAN PEMBAHASAN}

\section{Analisis Univariat}

Responden pada penelitian ini berjumlah 39 yang berasal dari semua perwakilan kelas $\mathrm{X}$ sebanyak 3-4 orang dengan rata-rata responden berumur 16 tahun (59\%). Berdasarkan tabel 1.2 perwakilan kelas hampir semua merata ada 3-4 orang untuk menjadi peer educator. Tabel 1.3 mengambarkan bahwa seluruh responden mengikuti kegiatan ekstrakulikuler. Aktif organisasi merupakan salah satu kriteria menjadi peer educator. Seluruh responden mengikuti kegiatan ekstrakulikuler dengan mayoritas $23,2 \%$ mengikuti ektrakulikuler rohis atau keagamaan Islam.

Tabel 1.4 mengambarkan bahwa 33.3 $\%$ responden mengidolakan artis Indonesia seperti Raisa, Maudy Ayunda, Agnes Monika dan Isyana Sarawati. Paparan media merupakan paparan informasi mengenai body image yang didapatkan sebelum pelatihan. Tabel 1.4 mengambarkan bahwa mayoritas atau sebanyak 43,6 \% responden belum pernah mendapatkan informasi mengenai body image dari manapun. Namun, 28,2\% mengatakan bahwa informasi yang didapatkan berasal dari internet. Sisanya sebanyak $12,8 \%$ mendapatkan infomasi dari majalah dan televisi.

Hasil univariat perbedaan skor pengetahuan, keterampilan dan skor body image sebelum dan sesudah pelatihan dapat 
dilihat pada Tabel 1.5. Tabel 1.5 menunjukan nilai efektifitas pengetahuan body image mengalami peningkatan $17.1 \%$, pengetahuan peer educator mengalami peningkatan $11.5 \%$, skor body image mengalami peningkatan sebesar $12.5 \%$ dan keterampilan mengalami peningkatan $43 \%$. Berdasarkan Tabel 1.5 menunjukan bahwa ada perbedaan sebelum dan sesudah pelatihan peer educator terhadap pengetahuan mengenai body image, pengetahuan mengenai peer educator, skor body image dan keterampilan dengan nilai A.sym.sig (2 tailed) 0.000. Hal ini sejalan dengan pelatihan peer educator rumah sahabat UDINUS mengenai kesehatan reproduksi remaja yang berhasil meningkatkan pengetahuan peserta pelatihan hingga 31\% (Mubarokah,2015).

Tabel 1.1. Distribusi Frekuensi Responden Berdasarkan Umur di SMAN 4 Purwokerto Tahun 2016

\begin{tabular}{lcc}
\hline $\begin{array}{c}\text { Umur } \\
\text { (tahun) }\end{array}$ & Frekuensi & $\begin{array}{c}\text { Persentase } \\
(\%)\end{array}$ \\
\hline 15 & 15 & 38.5 \\
16 & 23 & 59.0 \\
17 & 1 & 2.6 \\
\hline Jumlah & 39 & 100 \\
\hline
\end{tabular}

Tabel 1.2. Distribusi Frekuensi Responden Berdasarkan Kelas di SMAN 4 Purwokerto Tahun 2016

\begin{tabular}{lcr}
\hline Kelas & Frekuensi & \multicolumn{1}{r}{ Persentase $(\%)$} \\
\hline X IPA 1 & 4 & 10.3 \\
X IPA 2 & 4 & 10.3 \\
X IPA 3 & 4 & 10.3 \\
X IPA 4 & 4 & 10.3 \\
X IPA 5 & 4 & 10.3 \\
\hline X IPA 6 & 3 & 7.7 \\
X IPS 1 & 4 & 10.3 \\
X IPS 2 & 4 & 10.3 \\
X IPS 3 & 4 & 10.3 \\
X IPS 4 & 4 & 10.3 \\
\hline Jumlah & 39 & 100 \\
\hline
\end{tabular}

Tabel 1.3. Distribusi Frekuensi Kegiatan Ekstrakulikuler Responden di SMAN 4 Purwokerto Tahun 2016

\begin{tabular}{lcr}
\hline Ekstrakulikuler & Frekuensi & Persentase (\%) \\
\hline Debat B.inggris & 1 & 2.6 \\
Desain grafis & 2 & 5.1 \\
Karawitan & 3 & 7.7 \\
Kewirausahaan & 2 & 5.1 \\
KIR & 2 & 5.1 \\
Merpati putih & 2 & 5.1 \\
Tari & 2 & 5.1 \\
Paduan suara & 5 & 12.8
\end{tabular}




\begin{tabular}{lrr} 
Paskibra & 2 & 5.1 \\
PMR & 2 & 5.1 \\
Pramuka & 5 & 12.8 \\
Rohis & 9 & 23.1 \\
Volley & 1 & 2.6 \\
\hline Jumlah & 39 & 100 \\
\hline
\end{tabular}

Tabel 1.4 Distribusi Frekuensi Idola dan Paparan Media Responden di SMAN 4 Purwokerto Tahun 2016

\begin{tabular}{lrr}
\hline Karakteristik & Frekuensi & \multicolumn{2}{c}{ Persentase (\%) } \\
\hline Idola & & \\
\hline Artis Indonesia & 13 & 33.3 \\
Artis barat & 11 & 28.2 \\
Artis korea & 5 & 12.8 \\
Tidak ada & 10 & 25.6 \\
\hline Paparan Media & & \\
\hline Internet & 11 & 28.2 \\
Majalah & 5 & 12.8 \\
Televisi & 5 & 12.8 \\
Radio & 0 & 0 \\
Buku & 1 & 2.6 \\
Belum pernah & 17 & 43.6 \\
\hline Jumlah & 39 & 100 \\
\hline
\end{tabular}

Tabel 1.5. Perbedaan Skor efektifitas

\begin{tabular}{|c|c|c|c|c|c|c|}
\hline Variable & $\begin{array}{l}\text { Nilai } \\
\text { Terendah }\end{array}$ & $\begin{array}{l}\text { Nilai } \\
\text { Tertinggi }\end{array}$ & $\begin{array}{l}\text { Rata- } \\
\text { Rata }\end{array}$ & Efektifitas & $\begin{array}{c}A \\
\text { Sym. Sig. } \\
\text { (2-tailed) }\end{array}$ & $\alpha$ \\
\hline
\end{tabular}

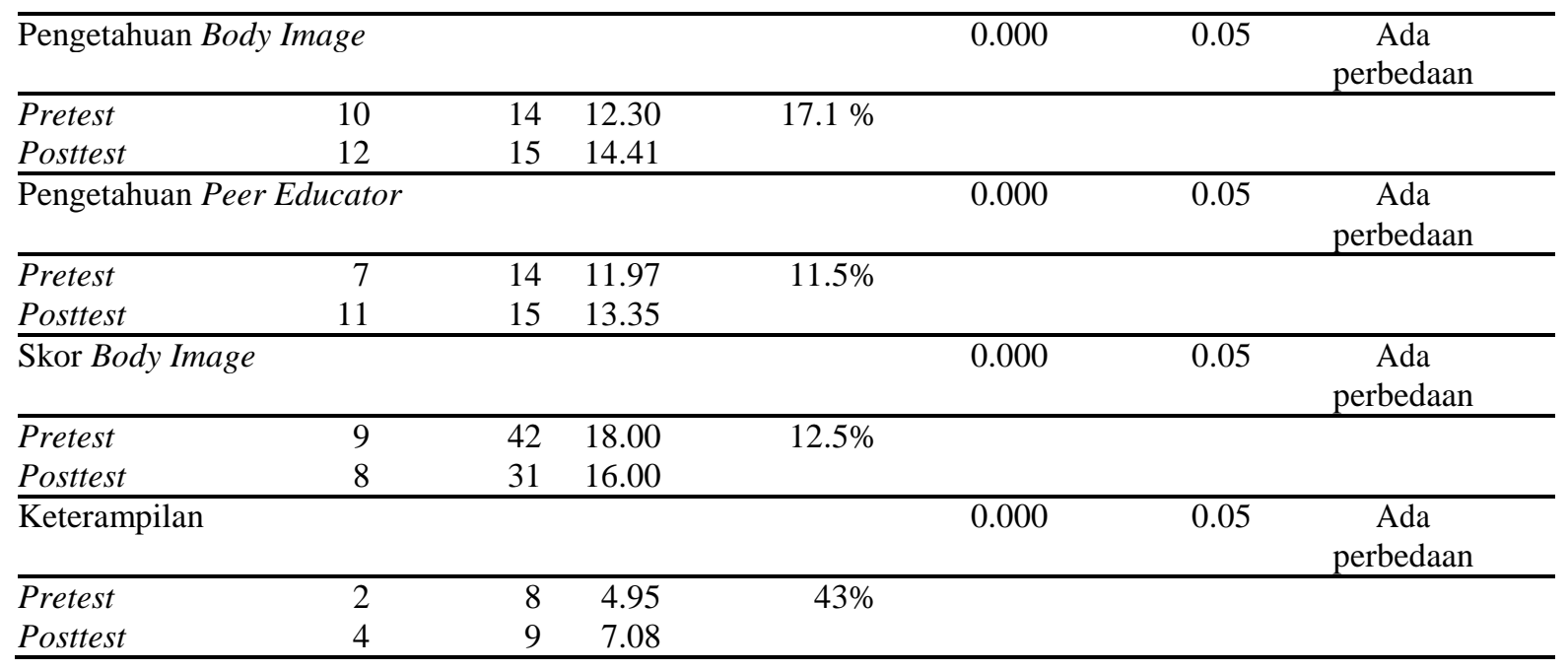


Terjadinya peningkatan pengetahuan tersebut sejalan dengan pendapat Notoatmodjo (2005) bahwa pelatihan memiliki tujuan penting dalam meningkatkan pengetahuan. Pelatihan ini menggunakan pendekatan pendidikan kesehatan. Berdasarkan Erika (2013) dalam penelitian mengenai efektifitas pendidikan kesehatan tentang pencegahan keputihan mengalami peningkatan tingkat pengetahuan remaja putri dari rata-rata $66,8 \%$ menjadi $75,5 \%$. Berdasarkan hasil pretest responden mengenai pengetahuan body image didapatkan nilai rata-rata 12.30 , hal ini karena 56,4 \% responden sudah terpapar informasi mengenai body image yang berasal dari televisi, internet, majalah dan buku dengan persentase terbesar $28.2 \%$ dari internet. Media massa adalah salah satu sumber informasi.Informasi yang banyak akan memperluas pengetahuan (Notoadmodjo,2003).

Berdasarkan hasil analisis menunjukan bahwa terdapat peningkatan nilai rata-rata pengetahuan mengenai peer educator sebelum dan sesudah pelatihan yaitu dari 11,97 menjadi 13,35 dan secara statistik menunjukan ada perbedaan pengetahuan yang signifikan sebelum dan sesudah pelatihan dengan rata-rata peningkatan skor $11.5 \%$. Hal ini sejalan dengan penelitian Mevsim (2008) mengenai penilaian pelatih pendidik sebaya dalam jangka pendek dan jangka panjang dengan hasil post-test sebelum dan sesudah pelatihan didapatkan peningkatan pengetahuan 21,6\% Hal ini sejalan dengan teori yang dikemukakan oleh Notoatmodjo (2007) penyuluhan kesehatan merupakan media promosi kesehatan yang dapat mempengaruhi pengetahuan seseorang. Beensley dan Fisher (2008) mengungkapkan bahwa pendidikan kesehatan memang menyampaikan informasi dengan harapan bahwa peserta didik akan mempelajarinya dan dapat mempengaruhi pengetahuannya.

Hasil uji bivariate menunjukan bahwa terdapat penurunan nilai rata-rata skor body image responden sebelum dan sesudah pelatihan yaitu dari 18.00 menjadi 16.00 . Semakin kecil skor body image maka akan semakin positif body imagenya. Secara statistik menunjukan ada perbedaan skor body image yang signifikan sebelum dan sesudah pelatihan. Penurunan nilai rata-rata skor body image antara pre test dengan post test yaitu sebesar $12.5 \%$. Hal ini sejalan dengan penelitian yang dilakukan oleh Wood (2004) mengenai pengaruh program intervensi media menunjukan adanya 
peningkatan body image dan perilaku makan sebelum dan sesudah perlakuan, Hal-hal yang mempengaruhi body image salah satunya media massa. Berdasarkan hasil analisis deskriptif didapatkan bahwa $33.3 \%$ responden mengidolakan artis Indonesia seperti Raisa, Maudy Ayunda, Agnes Monika dan Isyana Sarawati. Hal ini juga diperkuat dan didukung oleh tayangan-tanyangan media baik media cetak maupun elektronik. Pengaruh media sangat besar karena remaja adalah konsumen utama dalam berbagai tanyangan media-media tersebut dibuktikan dengan $30.8 \%$ responden rutin menonton sinetron di televisi dan $20.8 \%$ responden rutin menonton drama korea.

Keterampilan adalah tindakan yang dilakukan oleh peserta didik sehubungan dengan materi pendidikan yang diberikan (Notoatmodjo,2007). Hasil menunjukan bahwa terdapat peningkatan nilai rata-rata skor keterampilan responden sebelum dan sesudah pelatihan yaitu dari 4,95 menjadi 7,08. Hasil uji statistik dengan menggunakan uji wilcoxon diperoleh nilai Asymp. Sig. (2tailed $)=0,000 \quad(<0,05), \quad$ artinya secara statistik menunjukan ada perbedaan keterampilan yang signifikan sebelum dan sesudah pelatihan. Hal ini sejalan dengan hasil penelitian Rahmawati, (2015) mengenai pelatihan keterampilan konseling berbasis modul dapat meningkatkan keterampilan dasar konseling konselor sebaya PIK R MAN Yogyakarta 1 yang dilihat dari rata-rata persentase dari $34,42 \%$ menjadi $73,85 \%$. Pemberian pelatihan merupakan suatu proses belajar untuk memberikan keterampilan baru guna pengembangan sumber daya manusia (Maulana, 2009). Indikator efektivitas pelatihan dapat dilihat dari beberapa indikator diantaranya tambahan pengetahuan atau kemampuan peserta atau wawasan, kemampuan peserta mengingat isi pelatihan atau kemampuan peserta mempraktikan materi pelatihan atau trampil (Hasibuan, 2003).

\section{SIMPULAN DAN SARAN}

Efektifitas pelatihan peer educator remaja putri SMAN 4 Purwokerto terbukti efektif, karena secara nyata telah meningkatkan pengetahuan, skor body image, keterampilan dengan nilai A.sym.sig (2 tailed) 0.000. Pelatihan peer educator efektif meningkatkan pengetahuan tentang body image dengan peningkatan nilai rata-rata skor pengetahuan antara pre test dengan post test yaitu sebesar $17.1 \%$, pengetahuan tentang peer educator dengan peningkatan nilai ratarata sebesar $11.5 \%$. Penurunan nilai rata-rata 
skor body image peer educator yaitu sebesar $12.5 \%$. Semakin kecil skor body image semakin baik dan meningkatkan keterampilan menjadi peer educator dengan peningkatan sebesar 43\%. Pihak sekolah sebaiknya mengaktifkan kelompok peer group yang sudah dibentuk bernama " $B E$ CARE" menjadi peer educator yang bertugas menyebarkan ilmu yang sudah didapat mengenai body image dan selanjutnya bisa rutin diberikan pendidikan kesehatan lain.

\section{DAFTAR PUSTAKA}

Bensley, R. J., Fisher, J. B. 2008. Metode Pendidikan Kesehatan Masyarakat. Jakarta: EGC.

Brown, J.E., Janet.I. dan Bae.K, 2005, Nutrition throught the life cycle 2 nd edition, United States of America, Thompson Wadsworth.

Erika, D., 2013, Efektifitas Pendidikan Kesehatan Terhadap Tingkat Pengetahuan Remaja Perempuan Tentang Pencegahan Keputihan di SMK YMJ CIPUTAT, Skripsi, Universitas Islam Syarif Hidayatullah.

Esther, 2002, Hubungan antara sikap terhadap persuasi untuk bertubuh ideal menurut media dan harga diri dengan body dissatisfaction, Skripsi, tidak diterbitkan, Fakultas Psikologi Universitas Surabaya, Surabaya.

Gibney, M.J., Marianne.W., Lorraine.B., Helen.M.R., Bruce. G., Ben.V. O.,2005, Clinical Nutrition. Oxford: Blackwell Science,Ltd.

Hasibuan, M, S.P., 2003, Manajemen Dasar, Pengertian dan Masalah, Jakarta,PT Toko Gunung Agung.

Kozier, 2004, Fundamental Of Nursing: Concepts, Process And Practice, New Jersey,Pearson prentice hall

Maulana, H.D.J.,2009. Promosi Kesehatan.Jakarta:

EGC

Mevsim, V., Guldal, D., Ozcakar, N., Saygin, O.,2008. What was retained? The assessment of the training for the peer trainers' course on short and long term basis.

Mubarokah. K dan Eko .H.,2015, Pelatihan Peers (Peer Educator Rumah Sahabat Udinus) Dengan Motivasi Abati "Aku Bangga Aku Tahu Aku Berbagi" Tentang Kesehatan Reproduksi Remaja. Laporan Akhir Program Ipteks Bagi Masyarakat (Ibm), Universitas dian nusawantoro, Semarang.

Notoatmodjo, S.. 2003. Pendidikan Dan Perilaku Kesehatan. Rineka Cipta. Jakarta.

Notoatmodjo, S.,2005,Promosi Kesehatan Teori dan Aplikasi,Jakarta,Rineka Cipta.

Notoatmodjo, S.,2007,Perilaku Kesehatan Dan Ilmu Perilaku, Jakarta,PT Rineka Cipta

Papalia, Old, dan Feldman.,2008, Human Development (Psikologi Perkembangan). Jakarta, Kencana.

Rahayu, D., 2008,Efektivitas Promosi Kesehatan Dengan Metode Peer Educator Terhadap Tingkat Pengetahuan Dan Sikap Remaja Tentang Hiv/Aids, Skripsi Fakultas Kesehatan Masyarakat Universitas Muhammadiyah Surakarta.

Rahmawati, A.H., 2016. Peningkatan Keterampilan Konseling Konselor Sebaya Pusat Informasi Dan Konseling Remaja Man Yogyakarta 1. Prodi bimbingan dan konseling. Yogyakarta

Syarafina, A., dan Probosari, E.,2014, Hubungan Eating Disorder Dengan Status Gizi Pada Remaja Putri Di Modeling Agency Semarang, (http://ejournals1.undip.ac.id/index.php/jnc/. Diakses pada tanggal 1 Agustus 2016)

Wood, Kelsey A, 2004, Effects ofa Media Intervention Program on BodyImage and Eating Attitudes Among Children, UW-L Journal of Undergraduate Research $V$ 